\title{
ANÁLISE TECTÔNICA DO SEGMENTO CENTRAL DA ZONA DE CISALHAMENTO PERNAMBUCO LESTE, PROVÍNCIA BORBOREMA, NE DO BRASIL
}

\author{
Rafaela Henrique Mendes França ${ }^{1}$ \\ Sérgio Pacheco Neves ${ }^{2}$ \\ João Pedro Santana Bezerra ${ }^{1}$
}

10.18190/1980-8208/estudosgeologicos.v28n2p32-52

${ }^{1}$ Programa de Pós-Graduação em Geociências - UFPE, e-mail: henrique.rafaela@yahoo.com.br; jpsbezerra@hotmail.com

${ }^{2}$ Departamento de Geologia - UFPE; serpane36@yahoo.com

\section{RESUMO}

Este trabalho apresenta dados de campo, petrográficos, aerogeofísicos e de sensoriamento remoto de ortognaisses que ocorrem no segmento central da zona de cisalhamento Pernambuco Leste (ZCPE), Bezerros (PE). O principal objetivo foi analisar a influência da ZCPE na evolução geodinâmica da Província Borborema. A interpretação dos mapas aerogeofísicos gamaespectrométricos permitiu a caracterização das litologias em relação aos seus teores de radioelementos $(\mathrm{K}$, Th e $\mathrm{U})$. A caracterização estrutural da área de estudo realizada a partir de dados geofísicos e de sensoriamento remoto (ASTER-GDEM) evidenciou o predomínio de lineamentos de direção NE-SW, resultantes de foliações a norte e a sul da ZCPE. As rochas miloníticas apresentam feições microestruturais de deformação a temperaturas relativamente baixas $\left(400-500^{\circ} \mathrm{C}\right)$, com grãos de quartzo apresentando extinção ondulante e recristalização por rotação de subgrãos e, mais raramente, bulging. A interpretação integrada dos dados proporcionou a delimitação das faixas miloníticas na área em estudo. A análise das características estruturais apresentadas pelos domínios adjacentes, Rio Capibaribe (subprovíncia Central) e Pernambuco-Alagoas (subprovíncia Sul), permitiu identificar que a ZCPE não separa blocos crustais distintos. Portanto, o segmento central da ZCPE, não pode ser considerado como um limite de terreno tectônico.

Palavras chave: zona de cisalhamento Pernambuco Leste, ortognaisses, aerogeofísica, sensoriamento remoto, petrografia.

\begin{abstract}
This work describes field relationships and petrographic, aerogeophysical and remote sensing data from orthogneisses that occur in the central segment of the East Pernambuco shear zone (EPSZ), Bezerros (PE). The main objective is to analyze the influence of the EPSZ in the geodynamic evolution of the Borborema Province. The interpretation of aerogamma spectrometric maps allows the characterization of the lithologies with respect to their contents of radioelements $(\mathrm{K}, \mathrm{Th}, \mathrm{U})$. The structural characterization of the study area through geophysical and remote sensing data (ASTER-GDEM) evidenced the predominance of lineaments of NE-SW direction, resulting from the foliation trace north and south of the EPSZ. The mylonitic rocks display microstructural features of deformation at relatively low temperatures $\left(400-500^{\circ} \mathrm{C}\right)$, with quartz grains showing undulose extinction and recrystallization by subgrain rotation and, more rarely, bulging. The integrated interpretation of data allowed the delimitation of the mylonitic belts in the study area. The analysis of the structural characteristics displayed by the adjacent domains, Rio Capibaribe (Central sub-province) and Pernambuco-Alagoas (Southern sub-province) domains, allowed to establish that the EPSZ do not separate distinct crustal
\end{abstract}


blocks. Therefore, the central segment of the EPSZ, cannot be considered as a terrane limit.

Keywords: East Pernambuco shear zone, orthogneisses, aerogeophysics, remote sensing, petrography.

\section{INTRODUÇÃO}

Zonas de cisalhamento transcorrentes de escala continental são a principal expressão estrutural da orogênese Brasiliana-Pan-Africana na Província Borborema (p. ex. Caby et al., 1991; Vauchez et al., 1995). As zonas de cisalhamento são estruturas claramente observadas em fotografias aéreas, imagens de satélites e mapas geofísicos, como faixas lineares ou curvilíneas, referidas como lineamentos na literatura geológica antiga (Brito Neves, 1983). Um desses é o lineamento Pernambuco, que é tradicionalmente considerado como uma zona de cisalhamento transcorrente destral contínua, com 700 $\mathrm{km}$ de comprimento (p. ex. Davison et al., 1995; Brito Neves, 1983). Com forma sinuosa, o lineamento Pernambuco tem seus ramos leste e oeste com direções aproximadas N70-80E e N70W, respectivamente, a leste e a oeste da Bacia Jatobá. Posteriormente, Vauchez \& Edygio-Silva (1992) e Neves \& Vauchez (1995) sugeriram que estes dois segmentos são desconectados um do outro, como ramos independentes formando as zonas de cisalhamento Pernambuco Leste (ZCPE) e Oeste
(ZCPW) (Fig. 1). Neves \& Vauchez (1995) e Neves et al. (1996) estudaram uma porção central da ZCPE, mapeando um segmento de $35 \mathrm{~km}$ da mesma, a oeste da cidade de Caruaru. Posteriormente, Neves \& Mariano (1999) mapearam sistematicamente o segmento da ZCPE por inteiro, separando a ZCPE em várias faixas miloníticas e descrevendo-a como um sistema de zonas de cisalhamento.

Localizada no limite entre os domínios Rio Capibaribe (subprovíncia Central) e Pernambuco-Alagoas (subprovíncia Sul), separados pela ZCPE, a área de estudo encontra-se a leste da cidade de Caruaru, nos arredores da cidade de Bezerros, e compreende um trecho de aproximadamente $26 \mathrm{~km}$ da ZCPE. O objetivo principal deste trabalho foi caracterização estrutural do segmento central da ZCPE a partir da interpretação de dados aerogeofísicos (gamaespectrometria e magnetometria), imagens satelitais (ASTER-GDEM), dados de campo e petrografia, a fim de contribuir com o conhecimento acerca do sistema de zonas de cisalhamento Pernambuco Leste. 


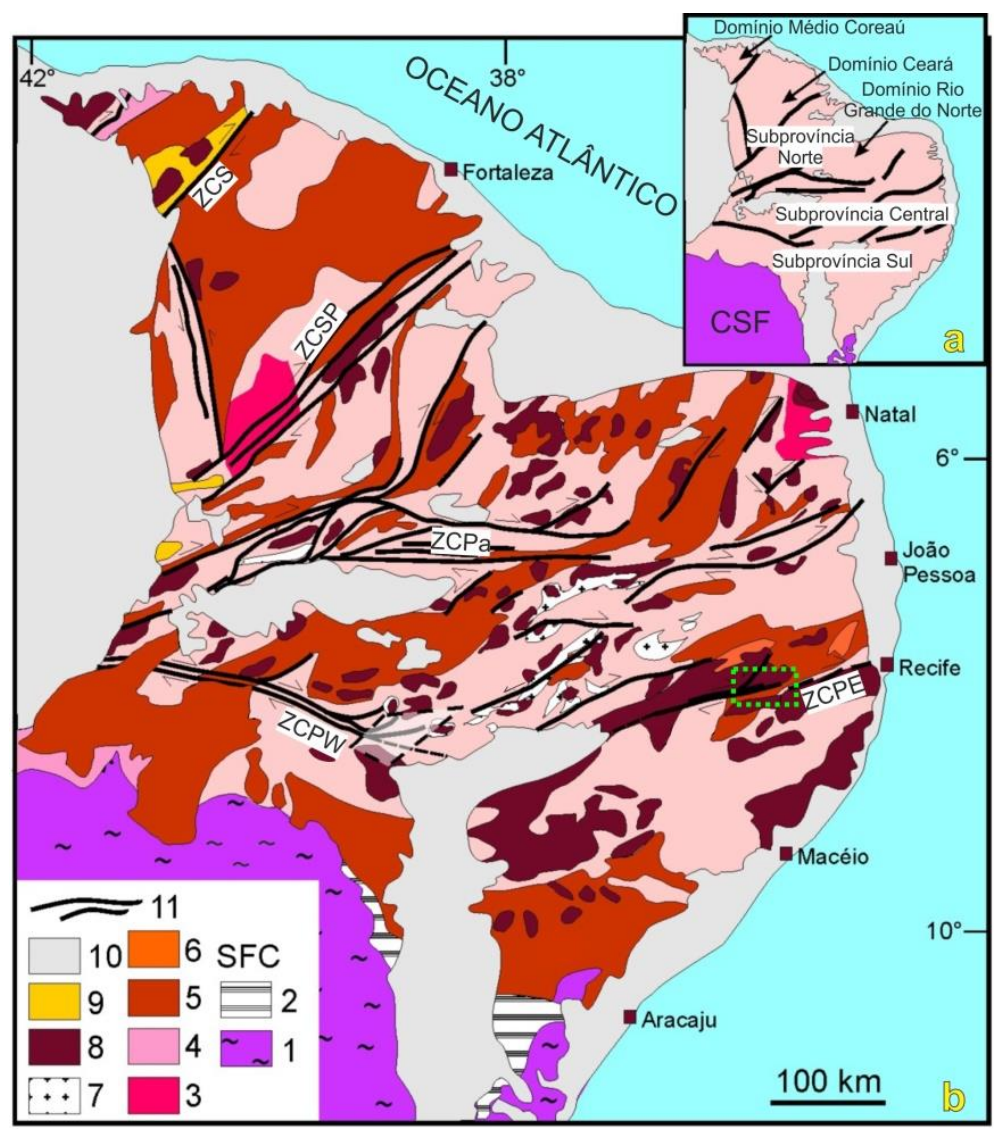

Figura 1. (a) Esboço dos principais domínios da Província Borborema. CSF: Cráton São Francisco. (b) Mapa geológico simplificado mostrando as principais áreas de exposição de embasamento ortognáissico, sequências supracrustais, plútons Brasilianos e zonas de cisalhamento. 1: Cráton São Francisco, 2: Cobertura cratônica, 3: Arqueano, 4: Paleoproterozoico, 5: Faixas metassedimentares, 6: Complexos Paleo/Mesoproterozoicos, 7: Ortognaisses Tonianos, 8: Plútons Brasilianos, 9: Molassas, 10: Cobertura Fanerozoica, 11: Principais zonas de cisalhamento transcorrentes: ZCS zona de cisalhamento Sobral; ZCSP - zona de cisalhamento Senador Pompeu; ZCPa zona de cisalhamento Patos; ZCPE - zona de cisalhamento Pernambuco Leste; ZCPW zona de cisalhamento Pernambuco Oeste. Cidades: Fortaleza, Natal, João Pessoa, Recife, Maceió, Aracaju. A localização aproximada da área de estudo encontra-se em destaque. Figura adaptada de Neves (2003).

\section{GEOLOGIA REGIONAL}

A Província Borborema é um dos muitos cinturões Brasilianos-PanAfricanos no Brasil e na África que resultaram da convergência e colisão de blocos continentais arqueanos e paleoproterozoicos durante a amalgamação do Gondwana Ocidental. A província é dividida em subprovíncias e domínios (p. ex. Van Schmus et al., 2011; Neves, 2015), separados por zonas de cisalhamento transcorrentes (Fig. 1) aparentemente tardias à evolução tectônica da província (Vauchez et al., 1995). A ZCPE, ao longo da qual se localiza a área de estudo, se estende da costa para oeste por mais de $200 \mathrm{~km} \mathrm{e}$ separa os domínios Rio Capibaribe (subprovíncia Central) e PernambucoAlagoas (subprovíncia Sul).

A ZCPE é segmentada em várias faixas miloníticas, sendo formada por duas faixas de alta temperatura (fácies anfibolito) e várias faixas de baixa temperatura (fácies xisto verde) (Neves \& Mariano, 1999). A área de estudo engloba a faixa milonítica de alta 
temperatura leste, que tem espessura máxima de $2 \mathrm{~km}$ e se conecta com zonas de cisalhamento de direção NE-SW de alta temperatura e cinemática sinistral, relacionadas ao batólito CaruaruArcoverde, e uma faixa milonítica de baixa temperatura ao sul que termina com um espalhamento em direções NESW e NNE-SSW para leste. Esta última é interpretada como o limite entre os domínios Rio Capibaribe e PernambucoAlagoas.

O domínio Rio Capibaribe consiste de rochas do embasamento, rochas supracrustais metassedimentares neoproterozoicas e plútons graníticos e sieníticos brasilianos (Neves et al., 2006b, 2009; Neves \& Alcantara, 2010). $\mathrm{Na}$ área de estudo (Fig. 2), o embasamento Paleoproterozoico é representado pelo ortognaisse Bezerros e pelo complexo Salgadinho. O complexo Salgadinho consiste de anfibólio-biotitaortognaisses com magnetita, migmatizado, de granulação média a grossa, com composição granodiorítica a sienogranítica (Neves et al., 2015b, 2017). O ortognaisse Bezerros, definido neste trabalho, tem composição granodiorítica a granítica, com granulação média a grossa e níveis locais ricos em biotita. As rochas supracrustais neoproterozoicas são representadas por micaxistos, paragnaisses, leucognaisses, rochas calcissilicáticas e mármores do complexo Surubim-Caroalina (Medeiros et al., 2000; Santos et al., 2002). O maior plúton Brasiliano é o batólito CaruaruArcoverde, consistindo de anfibólio- biotita-granitos de granulação grossa a porfiríticos e dioritos (Neves \& Mariano, 1999; Neves et al., 2000).

O domínio Pernambuco-Alagoas consiste dominantemente de ortognaisses frequentemente migmatizados, unidades surpracrustais e vários plútons e batólitos (p. ex. Brito Neves et al., 1982; Da Silva Filho et al., 2002). Dentre os ortognaisses representantes deste domínio, a unidade dominante na porção norte é o ortognaisse Altinho; bandado e de composição granodiorítica, localmente com porfiroclastos de feldspato potássico, com idade de c. $650 \mathrm{Ma}$ (Neves et al., 2015a; Teixeira, 2015). Na área estudada (Fig. 2), ocorrem além deste: um ortognaisse granítico migmatizado apresentando estrutura estromática, com presença local de bandas máficas; o ortognaisse Encruzilhada de São João, definido neste trabalho, que possui coloração cinza, granulação média a grossa, sendo comumente porfiroclástico e localmente equigranular; e o ortognaisse Caruaru, caracterizado por um biotita-anfibólioortognaisse, de composição granítica, equigranular de granulação grossa, com 618 Ma de idade (Neves et al., 2004, 2006a, 2012b). Intrusivos nos ortognaisses, ocorrem os plútons Cambão, caracterizado por biotitagranitos equigranulares de granulação média a grossa, e Encruzilhada de São João (Gomes, 2007), caracterizado por monzo- a sienogranitos a duas micas, de granulação fina a grossa. 


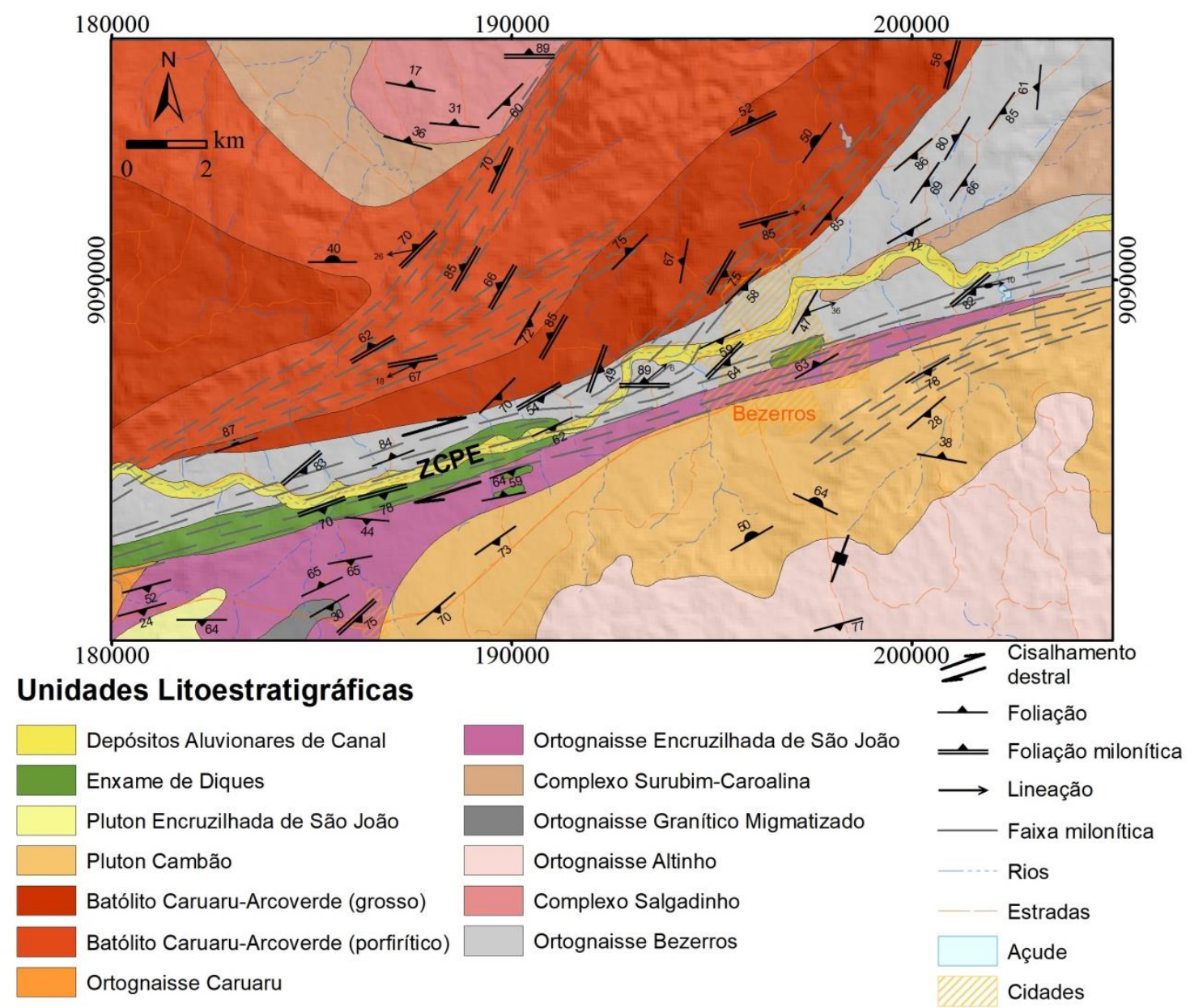

Figura 2. Mapa geológico-estrutural do segmento central da ZCPE (modificado de Neves et al., 2012a).

\section{MATERIAIS E MÉTODOS}

\section{Geofísica}

Os dados magnetométricos e gamaespectrométricos utilizados neste trabalho foram adquiridos durante $\mathrm{o}$ Projeto Aerogeofísico Borda Leste do Planalto da Borborema (código: 1079), cujas informações técnicas sobre levantamento e processamento dos dados podem ser obtidas no relatório final do projeto (LASA, 2008). Foram confeccionados e interpretados os mapas gamaespectrométricos de contornos radiométricos das concentrações de potássio, tório e urânio, o mapa da distribuição ternária desses radioelementos com padrão RGB (K, Th, U), e o mapa magnetométrico da derivada tilt (Fig. 3).

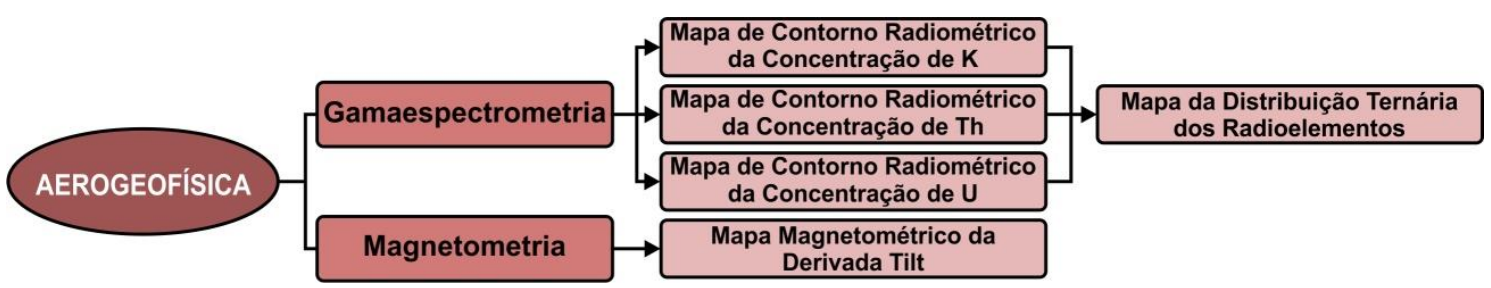

Figura 3. Fluxograma esquemático dos métodos geofísicos aplicados e mapas interpretados. 


\section{Sensoriamento remoto}

Imagens satelitais podem possuir feições conhecidas como bordas, que é o limite entre dois objetos espectralmente distintos, ou seja, o limite entre duas regiões com diferença significativa entre seus níveis de cinza (Meneses \& Almeida, 2012). Na geologia, exemplos de bordas podem ocorrer como lineamentos estruturais que, como ocorrem normalmente em várias direções, é importante realçá-las para uma melhor interpretação dos dados.

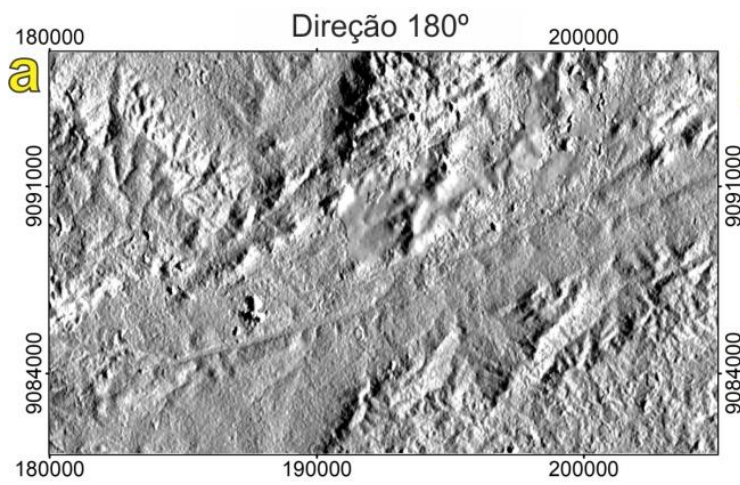

Com o intuito de destacar os lineamentos estruturais de diferentes direções que ocorrem na área em estudo, foi utilizada uma imagem ASTER, Global Digital Elevation Model - GDEM (NASA/METI; Earth Explorer-USGS), na qual foi aplicado filtro de borda direcional do tipo Kernel 3 x 3 em diferentes azimutes $\left(0^{\circ}, 45^{\circ}, 90^{\circ}, 135^{\circ}\right.$, $180^{\circ}, 225^{\circ}, 270^{\circ}, 315^{\circ}$ ), ressaltando a direção preferencial em que serão realçados os limites das bordas. Imagens representativas dos filtros aplicados são mostradas na figura 4 .

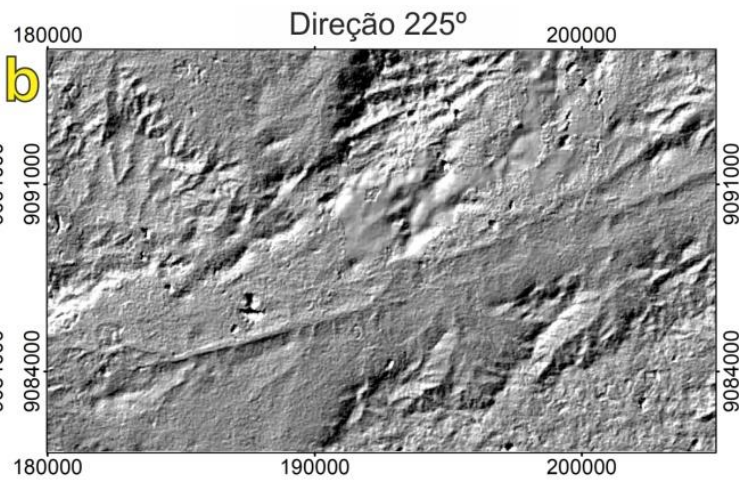

Figura 4. Imagens ASTER-GDEM com filtros de Kernel 3x3 nas direções (a) $180^{\circ}$ e (b) $225^{\circ}$.

\section{RESULTADOS}

\section{Gamaespectrometria}

Para a caracterização gamaespectrométrica das unidades mapeadas, foram interpretados os mapas de contagem individual dos radioelementos K (Fig. 5a), Th (Fig. 5b) e U (Fig. 5c), assim como o mapa da distribuição ternária desses elementos (Fig. 5d), responsável por condensar as informações obtidas nos três canais individuais. Uma possível lixiviação, devido à forte presença de drenagem na área de estudo pode ter ocorrido, sendo um dos possíveis fatores responsáveis por alterações nas respostas gamaespectrométricas das diferentes unidades. Porém, os dados de trabalhos de campo majoritariamente concordam com os dados de gamaespectrometria, evidenciando a importância da geofísica como ferramenta auxiliar ao mapeamento geológico.

$\mathrm{Na}$ figura 5d, observam-se os contatos das unidades do mapa geológico sobrepostos ao mapa da distribuição ternária dos radioelementos, a partir da qual foi possível melhor delimitar e caracterizar as unidades de acordo com as concentrações dos seus radioelementos. A norte da ZCPE, (1) o ortognaisse Bezerros apresenta assinatura radiométrica heterogênea descrita separadamente em duas porções. A nordeste do mapa, de cor preta esverdeada, possui contagens médias nos canais do $\mathrm{K}$ e $\mathrm{Th}$, e baixas contagens para o U. Mais próximo à ZCPE, apresenta coloração azul esbranquiçada, com contagens médias a altas para o três radioelementos. Essa diferenciação é possivelmente causada devido a alterações dadas pela drenagem do rio 
Ipojuca. (2) O complexo Salgadinho possui coloração roxa azulada e é melhor delimitado utilizando-se o canal do Th, no qual a unidade é caracterizada por conter de baixas a médias contagens, com contagens médias no canal do $\mathrm{K}$ e baixas a médias para o U. (3) $\mathrm{O}$ complexo Surubim-Caroalina, ocorrendo a nordeste e norte-noroeste, também apresenta heterogeneidade em sua composição radiométrica, explicável pela diferença topográfica entre essas duas regiões, observada pela presença de curvas de nível mais altas na ocorrência a nordeste. Ambas as regiões apresentam contagens médias a altas nos canais do $\mathrm{K}$ e Th, com variação nas contagens do canal do U, que são baixas a médias na região nordeste e médias a baixas na região norte-noroeste. Por fim, (4) o batólito Caruaru-Arcoverde apresenta assinaturas radiométricas características para cada uma de suas duas fácies, facilmente observável no mapa ternário e no canal do Th. A fácies do granito grosso (4a) é avermelhada e caracterizase por altas contagens no canal do $\mathrm{K}$, baixas a médias no canal do Th e médias a altas no U. Já a fácies do granito porfirítico (4b) possui altas contagens para os canais do $\mathrm{Ke} \mathrm{Th}$, e médias a altas no canal do $U$, o que justifica sua coloração esbranquiçada no mapa ternário.

A sul da ZCPE, (5) o ortognaisse Altinho, com coloração roxa avermelhada, se caracteriza por contagens médias a baixas nos canais do $\mathrm{K}$ e U, e baixas a médias no canal do Th, sendo o canal do Ko que melhor delimita a extensão do corpo. (6) O ortognaisse granítico migmatizado, azul esbranquiçado no mapa ternário, possui contagens altas no canal do $\mathrm{K}$ e médias a altas nos canais do Th e U, sendo melhor delimitado por este último canal. (7) $\mathrm{O}$ ortognaisse Encruzilhada de São João, avermelhado a esbranquiçado, é uma das unidades que possui sua assinatura radiométrica alterada pela proximidade com a ZCPE. Contém contagens altas no canal do K e médias a altas para o Th e $\mathrm{U}$, sendo o canal do Th o que melhor delimita o corpo. (8) O ortognaisse Caruaru, vermelho esbranquiçado no mapa ternário, não tem um canal que melhor demarque seus limites e sua assinatura radiométrica está provavelmente alterada devido à proximidade da ZCPE. Esta unidade possui contagens altas no canal do $\mathrm{K}$ e médias a altas nos canais do Th e U. (9) O plúton Cambão, tem coloração vermelha, refletindo as contagens altas no canal do K. Este plúton apresenta contagens baixas a médias nos canais de Th e U, e o canal do Th é o que melhor delimita esta unidade. (10) O plúton Encruzilhada de São João, esbranquiçado, se caracteriza por contagens altas nos canais do $\mathrm{Ke} \mathrm{Th}$, e altas a médias no canal do U. (11) O enxame de diques, que ocorre ao longo da ZCPE, possui sua assinatura radiométrica com altas contagens em todos os canais. (12) Os depósitos aluvionares de canal variam de branco a azulado, com contagens médias a altas para os três canais.

\section{Magnetometria}

O filtro da derivada tilt calcula a derivada da inclinação de um mapa, sendo aqui utilizado com o propósito de mapear estruturas encobertas rasas, ampliando as fracas anomalias magnéticas que geralmente são afetadas pelas anomalias mais fortes (Ribeiro et al., 2015). Definido por Miller \& Singh (1994), o filtro da derivada tilt é muito utilizado na delimitação de lineamentos, falhas e contatos geológicos (HidalgoGato, 2015). 

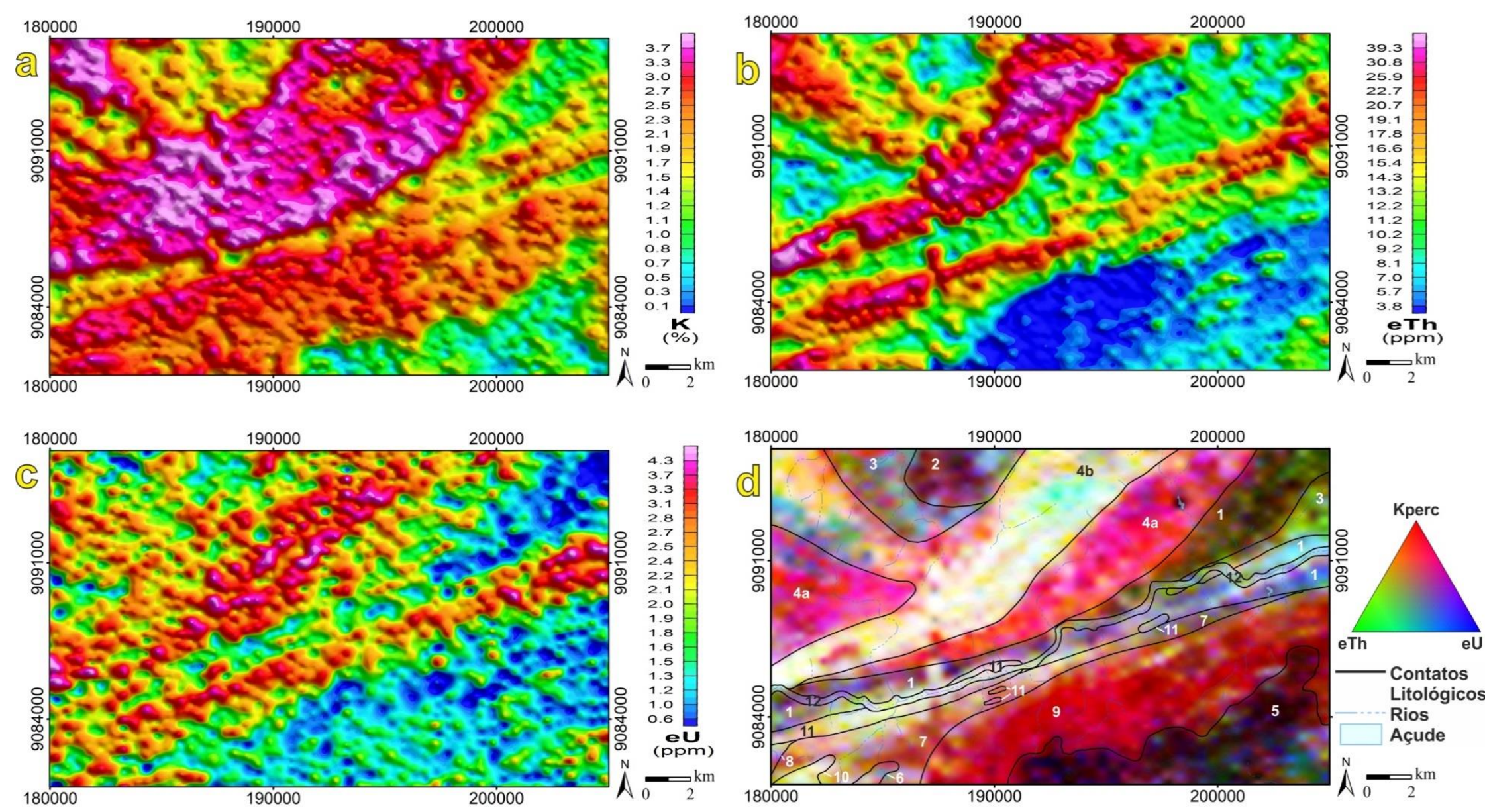

Figura 5. Mapas de contornos radiométricos das concentrações de (a) Potássio, (b) Tório e (c) Urânio e (d) mapa da distribuição ternária dos radioelementos (com padrão RGB $=\mathrm{K}$, Th, $\mathrm{U}$ ), sobreposto pelos contatos das unidades mapeadas na área de estudo. 1- Ortognaisse Bezerros, 2Complexo Salgadinho, 3- Complexo Surubim-Caroalina, 4- Batólito Caruaru-Arcoverde (4a - granito grosso; 4b - granito porfirítico), 5Ortognaisse Altinho, 6- Ortognaisse granítico migmatizado, 7- Ortognaisse Encruzilhada de São João, 8- Ortognaisse Caruaru, 9- Plúton Cambão, 10- Plúton Encruzilhada de São João, 11- Enxame de diques, 12- Depósitos aluvionares de canal. 
No mapa magnetométrico da derivada tilt foi marcado um total de 63 lineamentos (Fig. 6a), sendo classificados como 16 lineamentos curvilíneos, possivelmente resultantes de estruturas dúcteis, e 47 lineamentos retilíneos, resultantes de estruturas rúpteis. Estes últimos encontram-se detalhados na tabela 1 de acordo com suas direções preferenciais, separandoos em dois grupos, lineamentos de direção NE-SW e de direção NW-SE. Os lineamentos resultantes de estruturas dúcteis ocorrem majoritariamente nas porções centro-NW e centro-SE. Ambas as direções também possuem quantidades semelhantes de lineamentos resultantes de estruturas rúpteis, sendo os de direção NE-SW, os que possuem maior comprimento médio e maior diferença de extensão entre os lineamentos de maior e menor comprimento. Os dois maiores lineamentos marcados estão na direção NE-SW e são controlados pela ZCPE, que tem, na área de estudo, extensão total de $\sim 26 \mathrm{~km}$ e largura entre 1,1-1,6 km. Os lineamentos resultantes de estruturas rúpteis que ocorrem na direção $\mathrm{NW}$ encontram-se cortando a ZCPE, indicando que representam estruturas posteriores a mesma.

A partir dos lineamentos magnéticos relacionados a estruturas rúpteis, foi possível gerar diagramas de rosetas, utilizando intervalos de $15^{\circ}$, sendo um diagrama de roseta geral (Fig. 6b) e diagramas de roseta separados para lineamentos a norte (Fig. 6c) e a sul (Fig. 6d) da ZCPE. No geral (Fig. 6b), os lineamentos concentram-se nas direções $315^{\circ}$ (NW-SE) e $60-75^{\circ}$ (NE-SW), com ambos os domínios apresentando lineamentos nestas principais direções. A direção $315^{\circ}$ igualmente se destaca nos domínios, enquanto há maior concentração de lineamentos na direção $60^{\circ}$ a norte da ZCPE e na direção $75^{\circ}$ a sul da ZCPE.

\section{Lineamentos topográficos}

A partir da interpretação da imagem GDEM filtrada foi possível extrair um total de 127 lineamentos topográficos na área mapeada (Fig. 7a; tabela 2), sendo 67\% desses na direção NE-SW, que possui o maior e o menor lineamento marcados na área de estudo, medindo $12,53 \mathrm{~km}$ e $0,54 \mathrm{~km}$ de comprimento, respectivamente. 

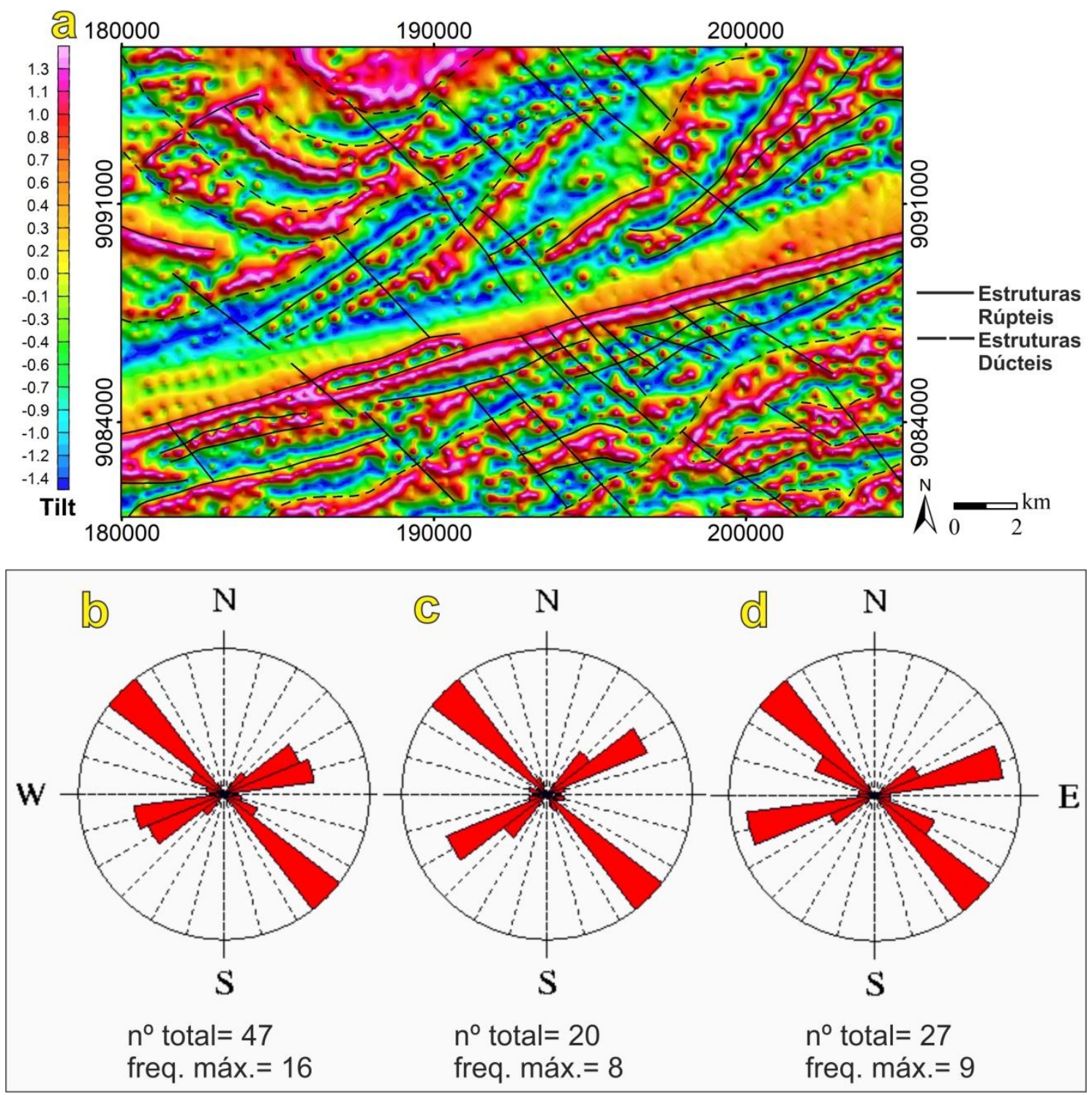

Figura 6. (a) Mapa da derivada tilt mostrando os lineamentos relacionados a estruturas rúpteis (linha sólida) e dúcteis (linha tracejada) marcados na área em estudo utilizando a magnetometria. Diagramas de roseta da direção dos lineamentos magnéticos relacionados a estruturas rúpteis: (b) gerais, (c) setor norte e (d) setor a sul da ZCPE.

Tabela 1. Números gerais dos lineamentos relacionados a estruturas rúpteis marcados na área de estudo, a partir do mapa da derivada tilt.

\begin{tabular}{ccccc}
\hline Direção & População & $\begin{array}{c}\text { Comprimento } \\
\text { Médio }(\mathbf{k m})\end{array}$ & $\begin{array}{c}\text { Maior } \\
\text { Lineamento } \\
(\mathbf{k m})\end{array}$ & $\begin{array}{c}\text { Menor } \\
\text { Lineamento } \\
(\mathbf{k m})\end{array}$ \\
\hline NE-SW & $23(49 \%)$ & 5,94 & 18,79 & 1,54 \\
NW-SE & $24(51 \%)$ & 4,10 & 8,52 & 2,38 \\
\hline
\end{tabular}



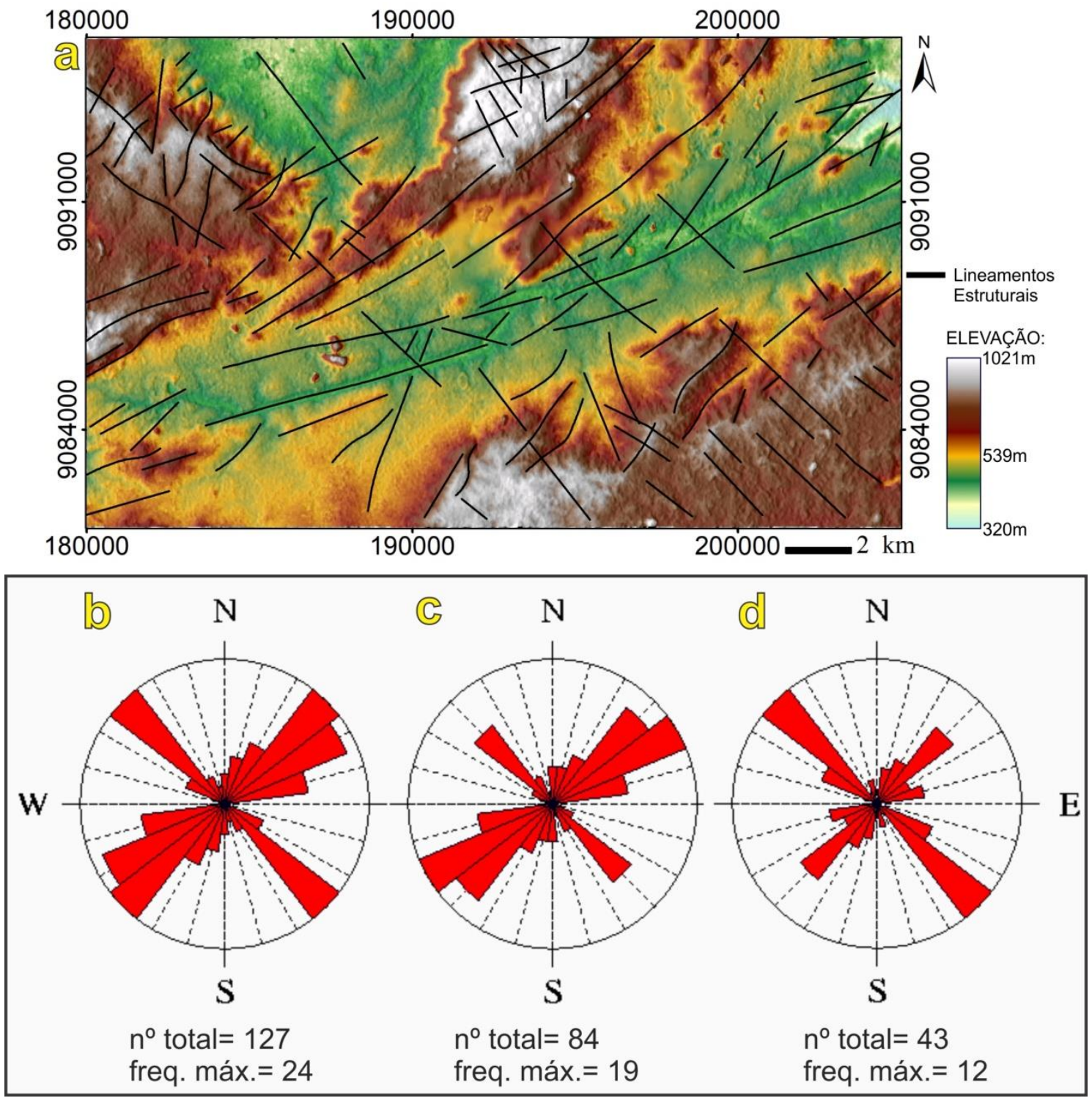

Figura 7. (a) Imagem ASTER-GDEM mostrando os lineamentos marcados utilizando-se das imagens filtradas nos diferentes azimutes. Diagramas de roseta da direção dos lineamentos topográficos: (b) gerais, (c) setor norte e (d) setor a sul da ZCPE.

Tabela 2. Números gerais dos lineamentos marcados na área de estudo, a partir da imagem ASTER-GDEM filtrada.

\begin{tabular}{ccccc}
\hline Direção & População & $\begin{array}{c}\text { Comprimento } \\
\text { Médio }(\mathbf{k m})\end{array}$ & $\begin{array}{c}\text { Maior } \\
\text { Lineamento (km) }\end{array}$ & $\begin{array}{c}\text { Menor } \\
\text { Lineamento (km) }\end{array}$ \\
\hline NE-SW & $85(67 \%)$ & 2,73 & 12,53 & 0,54 \\
NW-SE & $42(33 \%)$ & 2,15 & 5,17 & 0,67 \\
\hline
\end{tabular}

A partir dos lineamentos observados foram gerados um diagrama de roseta geral (Fig. 7b) e diagramas de roseta separados para lineamentos topográficos a norte (Fig. 7c) e a sul (Fig. 7d) da ZCPE. No geral (Fig. 7b), os lineamentos concentram-se nas direções $45^{\circ}$ (NE-SW) e $315^{\circ}$ (NW-SE). Ambos os domínios apresentam lineamentos nestas duas principais direções, com maior concentração de lineamentos NESW a norte da ZCPE e de lineamentos NW-SE a sul da ZCPE. Foi identificada uma predominância de lineamentos resultantes de estruturas dúcteis a norte da ZCPE, enquanto que a sul 
predominam lineamentos controlados por estruturas rúpteis. Uma maior concentração de lineamentos NE-SW a norte da ZCPE explica-se pelo fato da faixa milonítica se estender mais para norte do que para sul na área em estudo, sendo assim, o domínio norte, o mais afetado pela mesma.

Os lineamentos topográficos gerais podem então ser interpretados de acordo com as duas direções principais reconhecidas (NE-SW e NW-SE). A direção NE-SW é a principal, também pelo fato de seus maiores lineamentos (entre 12,5 e 4,4 km) serem aqueles que correspondem às zonas de cisalhamento, sendo também condizentes com dados de foliação milonítica e foliação de médio/alto ângulo. As foliações, no geral, são as estruturas melhores marcadas pelos lineamentos. Ocorrendo em ambos os domínios, muitos dos lineamentos de menor comprimento e de carácter mais curvilíneo são controladores de cursos de drenagem, da mesma forma, os medianos delimitam o contato entre unidades litoestratigráficas distintas.

\section{Mapa geológico-estrutural}

A figura 2 mostra o mapa geológico-estrutural da área de estudo, no qual encontram-se mapeados: (a) o embasamento paleoproterozoico, formado pelos ortognaisses dos complexos Salgadinho e Bezerros, (b) os ortognaisses neoproterozoicos, graníticos e granodioríticos, nomeados de Altinho, Encruzilhada de São João, Caruaru e o ortognaisse migmatizado não nomeado, (c) as rochas supracrustais neoproterozoicas do complexo SurubimCaroalina e (d) as intrusões neoproterozoicas do batólito CaruaruArcoverde e plútons Cambão e Encruzilhada de São João, além da intrusão das rochas do enxame de diques.

$$
\text { O ortognaisse granítico }
$$
migmatizado (Fig. 8a) possui presença local de bandas máficas e é afetado por, no mínimo, duas fases de dobramento. $\mathrm{O}$ bandamento migmatítico é afetado por dobras abertas (Fig. 8a) e localmente deformado por bandas de cisalhamento destrais (E-NE) e sinistrais (NE). Sua foliação principal tem direção NE-SW e mergulha com intensidade baixa a moderada $\left(30^{\circ}-56^{\circ}\right)$ para sudeste. Em uma porção milonitizada, há presença de dobra em Z indicando cinemática destral. Seu mesossoma (Fig. 9a-b) é inequigranular de granulação média, caracterizado pela alternância entre níveis ricos em quartzo e ricos em feldspatos (Fig. 9a). O quartzo apresenta extinção ondulante e intensa recristalização por rotação de subgrãos e migração de limites de grãos. Os feldspatos ocorrem como grãos arredondados de 0,5 a $2 \mathrm{~mm}$ de comprimento, algumas vezes formando augens simétricos. Eles podem apresentar-se fraturados e com textura manto-núcleo. O feldspato potássico é pertítico e pode conter mirmequita desenvolvida em seus contatos com grãos de plagioclásio. Este último, comumente apresenta maclas de deformação e geminações polissintéticas dobradas. Biotita é a única fase mineral máfica e pode compor até $6 \%$ da moda. A biotita pode seguir a foliação definida pelos níveis quartzo-feldspáticos, ocorrendo intersticialmente entre os minerais essenciais (Fig. 9b) ou preenchendo fraturas. As fases acessórias são formadas por zircão, minerais opacos e apatita. As fases secundárias são mica branca e epidoto, produzidos por sericitização e saussuritização dos feldspatos, respectivamente, além de clorita como produto de alteração da biotita.

$\mathrm{O}$ ortognaisse Encruzilhada de São João (Fig. 8b) tem composição granítica e textura caracteristicamente porfiroclástica, com megacristais de feldspato de até $1,5 \mathrm{~cm}$, sendo localmente equigranular. A foliação varia de NE-SW a NW-SE, com 
mergulho moderado $\left(\sim 65^{\circ}\right)$ para norte, localmente verticalizada devido à forte deformação transcorrente e relação com dobras verticais apertadas. Alguns afloramentos, levemente deformados, preservam megacristais com formas euédricas e possuem uma foliação com direção NW-SE e mergulho baixo $\left(6^{\circ}\right.$ $10^{\circ}$ ) para norte. A foliação é caracterizada pela alternância de níveis ricos em quartzo e feldspato e ricos em biotita e hornblenda, formando um bandamento mal definido. Porfiroclastos de feldspato $(\leq 5 \mathrm{~mm})$ e anfibólio $(2-4$ $\mathrm{mm})$ podem desenvolver cauda de recristalização. Biotita \pm anfibólio são comumente encontrados nas bordas dos porfiroclastos de feldspatos (Fig. 9c) e biotita \pm epidoto (+ eventual titanita) nas bordas dos porfiroclastos de anfibólio (Fig. 9d). Grãos fraturados podem ocorrer preenchidos por biotita. As fases acessórias são apatita, rutilo, titanita, minerais opacos e zircão. As fases secundárias são epidoto (associado à biotita, geralmente nas bordas de hornblenda, algumas vezes com núcleos de allanita e como produto da saussuritização de plagioclásio) e clorita (produto da desestabilização da biotita).

O ortognaisse Bezerros (Fig. 8cd) tem composição granodiorítica a granítica, granulação de média a grossa e níveis locais ricos em biotita. A foliação gnáissica (Fig. 8c) tem direção NE-SW e mergulho de moderado a alto para sudeste, com textura aproximadamente equigranular e sem formação de porfiroclastos ou sigmoides. Ao se aproximar da ZCPE (Fig. 8d), a foliação milonítica tem direção NE-SW e mergulho subvertical $\left(59-77^{\circ}\right)$ para sudeste, com lineação com baixo caimento para nordeste (provavelmente sin-transcorrente) a horizontal. Porfiroclastos simétricos e assimétricos são comumente observados, este último indicando cinemática destral, também observada por bandas de cisalhamento destrais locais e trama S-C. Há afloramentos localmente migmatizados, apresentando dobras isoclinais na porção granítica. A microestrutura dominante consiste de finos níveis de biotita alternando com níveis quartzofeldspáticos mais espessos (Fig. 9e). Onde a biotita não é suficientemente abundante para formar níveis contínuos, ela ocorre como grãos isolados ou agregados de grãos ao redor de porfiroclastos de feldspatos (Fig. 10f-g). Os níveis quartzo-feldspáticos (Fig. 9f) são compostos por porfiroclastos de feldspatos $(\leq 5 \mathrm{~mm})$, principalmente plagioclásio, e grãos de quartzo recristalizados e mais finos. Esta unidade tem menos minerais máficos do que o ortognaisse Encruzilhada de São João e hornblenda foi identificada como fase acessória (1\%) em apenas uma amostra. As fases acessórias comumente encontradas são zircão, apatita, rutilo e minerais opacos. Porfiroclastos de granada ocorrem nas amostras ao longo da ZCPE, em grãos muito fraturados e alterados para clorita, em suas bordas e ao longo de fraturas. Micas, predominantemente biotita, podem ocorrer em suas bordas, e grãos de quartzo e mica como inclusões, indicando origem metamórfica para a granada. As fases secundárias são resultantes da sericitização e saussuritização dos feldspatos, como mica branca e epidoto, respectivamente, e opacitização e cloritização da biotita.

Milonitos granodioríticos equigranulares finos, interpretados como pertencentes ao enxame de diques previamente mapeado nos arredores da cidade de Bezerros (Neves et al., 2012a), foram observados em duas localidades, sendo rochas mais máficas (Fig. 8e) do que os gnaisses. A foliação milonítica tem direção NE-SW e mergulha para sul e para norte com valores de $59^{\circ}$ e $64^{\circ}$, respectivamente. Estas rochas (Fig. 9gh) são caracterizadas pela alternância entre bandas félsicas quartzo $(0,5-0,1$ $\mathrm{mm}$ )-feldspáticas $(<1,5 \mathrm{~mm})$ e bandas 
máficas compostas por anfibólio e agregados de epidoto (Fig. 9g). A foliação da rocha é controlada principalmente pela orientação de grãos de anfibólio, quartzo e feldspatos. Grãos de epidoto, actinolita, minerais opacos (associados com titanita e epidoto) e titanita (associada aos minerais opacos e epidoto) foram aparentemente gerados a partir da hornblenda, indicando intensa retrogressão. Podem ocorrer porções com grãos de feldspatos totalmente alterados por sericitização e/ou saussuritização, conferindo um aspecto nebuloso aos grãos (Fig. 9h). As fases acessórias são apatita e zircão (como inclusões em grãos de anfibólio). As fases secundárias são mica branca e epidoto produzidos, respectivamente, pela sericitização e saussuritização dos feldspatos. No ponto RAF-07 a granulação é mais fina, com microcisalhamento e o processo de retrogressão encontra-se menos avançado. Biotita agora está presente como uma fase acessória e mineral carbonático é produzido por saussuritização.
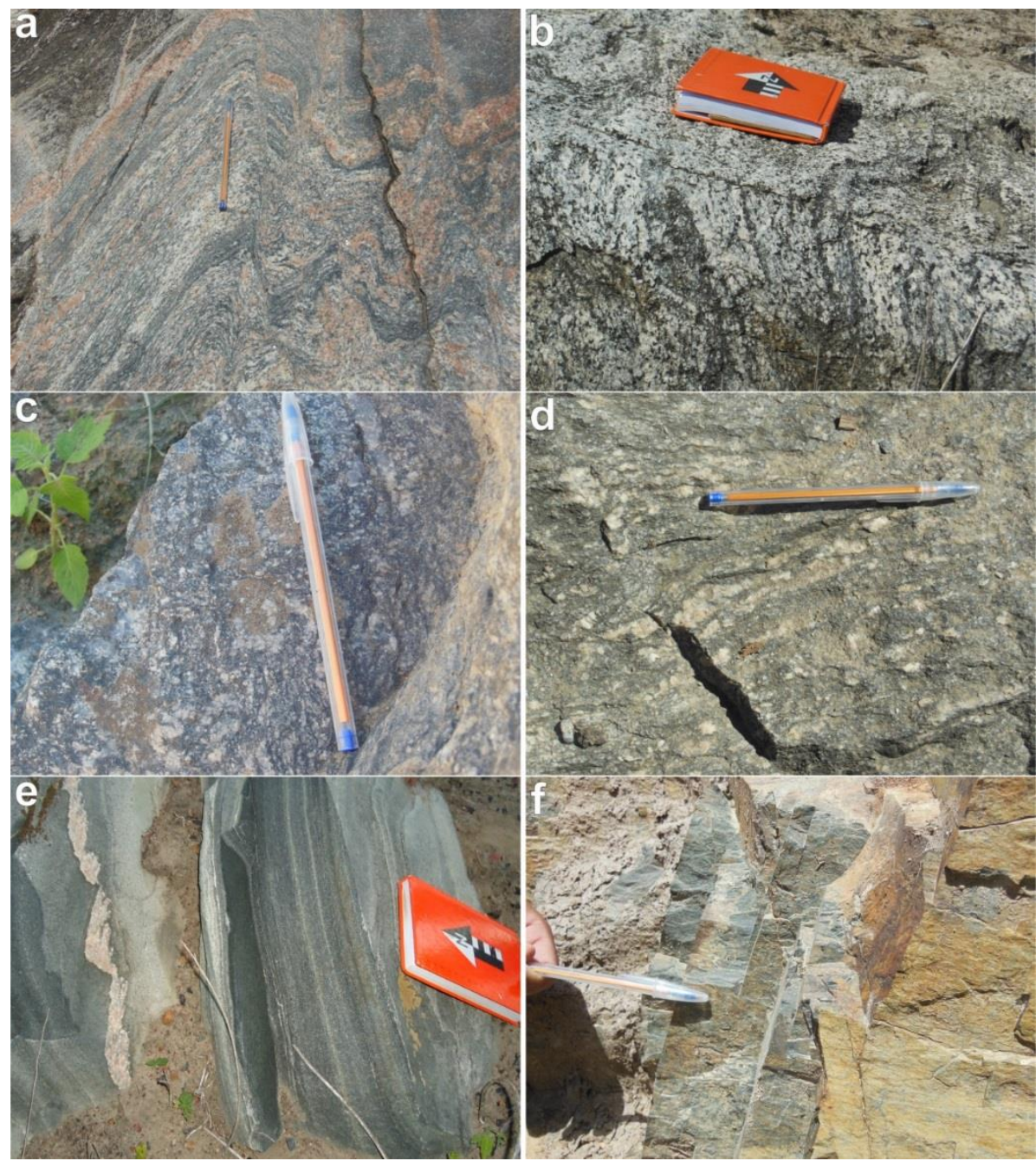

Figura 8. Aspectos de campo dos ortognaisses mapeados: (a) Ortognaisse granítico migmatizado, com foliação transposta. (b) Ortognaisse Encruzilhada de São João, granítico, com foliação verticalizada devido à presença de dobramentos. (c-d) Ortognaisse Bezerros, granodiorítico a granítico, com (c) foliação gnáissica regional e (d) foliação milonítica. (e) Ortognaisse equigranular fino (Enxame de diques). (f) Ultramilonito a norte da ZCPE. 


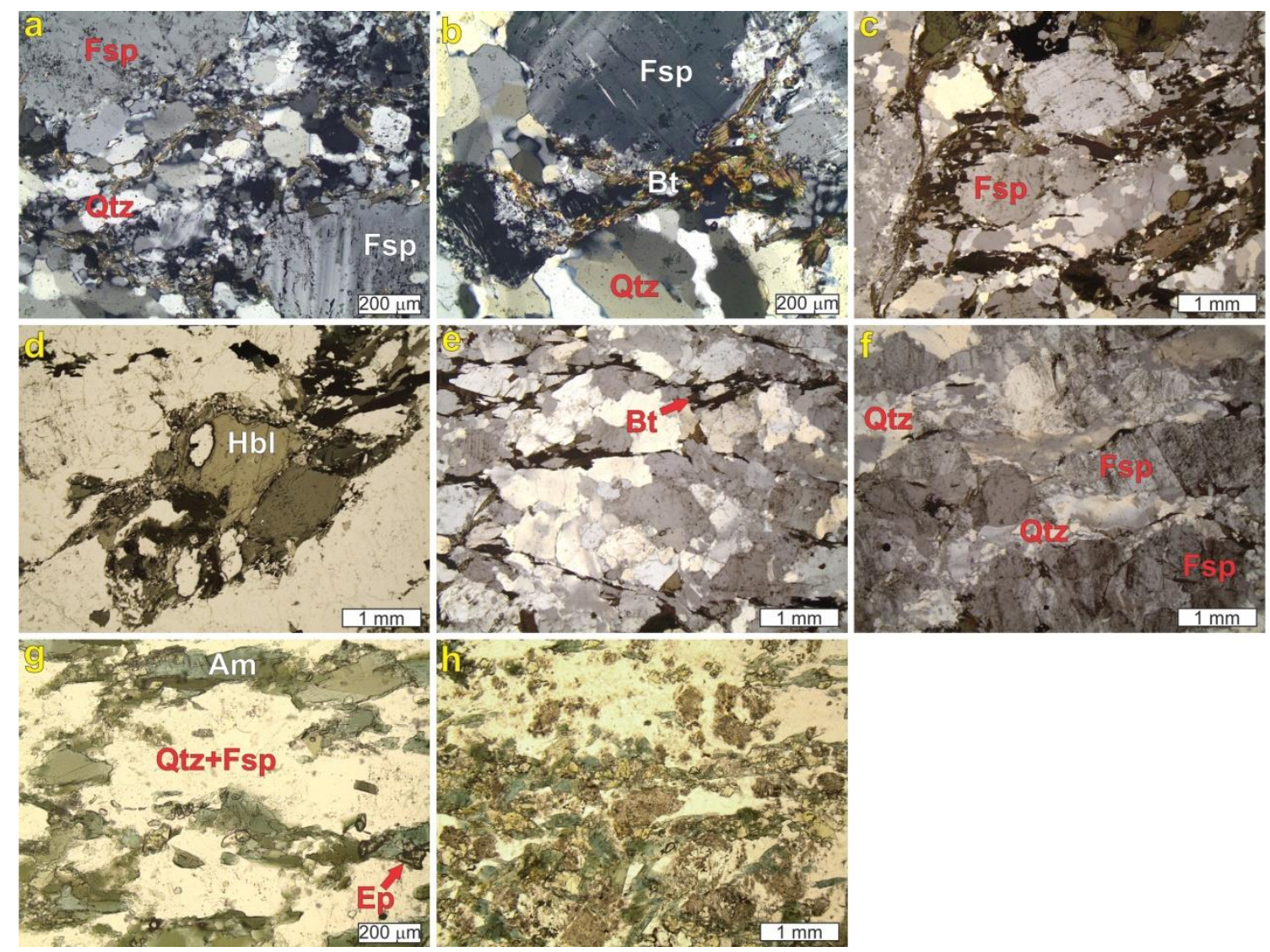

Figura 9. Características microestruturais dos ortognaisses mapeados. (a-b) Ortognaisse granítico migmatizado apresentando (a) alternância entre níveis ricos em quartzo e ricos em feldspatos e (b) biotita intersticial entre estes níveis (ambas com polarizadores cruzados). (c-d) Ortognaisse Encruzilhada de São João evidenciando (c) biotita \pm anfibólio em bordas de porfiroclastos de feldspato e (d) biotita土epidoto em bordas dos porfiroclastos de anfibólio (polarizadores cruzados e paralelos, respectivamente). (e-f) Ortognaisse Bezerros mostrando (e) finos níveis de biotita e níveis quartzo-feldspáticos e (f) porfiroclastos de feldspatos e grãos de quartzo recristalizados (ambas com polarizadores cruzados). (g-h) Rocha do enxame de diques mostrando (g) alternância entre as bandas máficas $(A m+E p)$ e félsicas $(Q t z+F s p)$ e $(h)$ grãos de feldspato totalmente alterados exibindo aspecto nebuloso (ambas com polarizadores paralelos). Am: anfibólio, Bt: biotita, Ep: epidote, Fsp: feldspato, $\mathrm{Hbl}$ : hornblenda, Kf: feldspato potássico, Pl: plagioclásio, Qtz: quartzo.

\section{FAIXAS MILONÍTICAS}

A ZCPE é uma estrutura de fácil identificação em escala regional, encontrando-se bem marcada por geofísica e sensoriamento remoto pelos maiores lineamentos de direção ENEWSW (Fig. 6a e 7a). Com base nas faixas miloníticas de alta e de baixa temperatura previamente estabelecidas (Neves \& Mariano, 1999) e dados de campo de mapeamentos prévios (Neves et al., 2012a), adicionado as características petrográficas dos ortognaisses em questão, foram definidas as faixas miloníticas presentes na área de estudo.

As faixas miloníticas (Fig. 2) se caracterizam como uma faixa principal de direção ENE-WSW, com espessura variando de 1 a $1,4 \mathrm{~km}$, que está presente nas rochas encaixantes, sendo a principal faixa milonítica destral compreendida pela ZCPE. Esta faixa se conecta com outras de direção NE-SW, espessura 
variando de 1 a $1,8 \mathrm{~km}$, que se estendem a norte e a sul da ZCPE, no interior do batólito Caruaru-Arcoverde e plúton Cambão, respectivamente. Ao longo das faixas miloníticas que afetam as rochas encaixantes, foram classificados milonitos e ultramilonitos de baixa a média temperatura dos ortognaisses $\left(400-500^{\circ} \mathrm{C}\right) \quad$ com base nas microestruturas presentes. Assim como as feições microestruturais, a associação metamórfica (p. ex. epidoto, clorita, actinolita) também é típica de deformação a temperaturas relativamente baixas.

Os protólitos dos milonitos estudados são derivados de rochas intrudidas no enxame de diques e das rochas encaixantes, os ortognaisses Encruzilhada de São João e Bezerros. Estes protólitos apresentam grãos de quartzo estirados com extinção ondulante (Fig. 10a-b) e recristalizados (Fig. 10c-d). Os grãos de feldspatos são fraturados (Fig. 10e-f) e, às vezes, apresentam maclas de deformação e geminações dobradas, e os de biotita encontram-se recristalizados em grãos finos ao redor dos porfiroclastos (Fig. 10f-g). Estruturas assimétricas utilizadas como indicadores cinemáticos encontram-se presentes, mas não bem desenvolvidas, como porfiroclastos de feldspatos com cauda de recristalização e trama S-C. Em milonitos de temperatura um pouco mais elevada, o quartzo passa a recristalizar em grãos maiores (> $50 \mu \mathrm{m})$ por rotação de subgrãos (Fig. 10h) e pode apresentar trama poligonal resultante de redução de área (Fig. 10i), enquanto os feldspatos encontram-se com recristalização incipiente (Fig. 10j), com textura mantonúcleo, e raras mirmequitas podem estar presentes na borda de feldspato potássico (Fig. 10k).

Nos ultramilonitos (Fig. 8f) os grãos maiores alcançam no máximo 56 $\mu \mathrm{m}$, sendo constituídos por quartzo apresentando extinção ondulante e, prováveis grãos de feldspatos, de difícil identificação devido ao alto grau recristalização. A recristalização destes grãos félsicos produziu grãos mais finos que formam a matriz, composta também por biotita e clorita já em estágios mais avançados de recristalização. $\mathrm{O}$ bandamento milimétrico é caracterizado pela alternância entre níveis quartzofeldspáticos e ricos em filossilicatos (Fig. 101). São observáveis microdobras e microfalhas, este último indicando movimentação sinistral. O protólito do mesmo é de difícil identificação, a amostra encontra-se no contato entre o batólito Caruaru-Arcoverde e o ortognaisse Bezerros, no extremo oeste do mapa. 

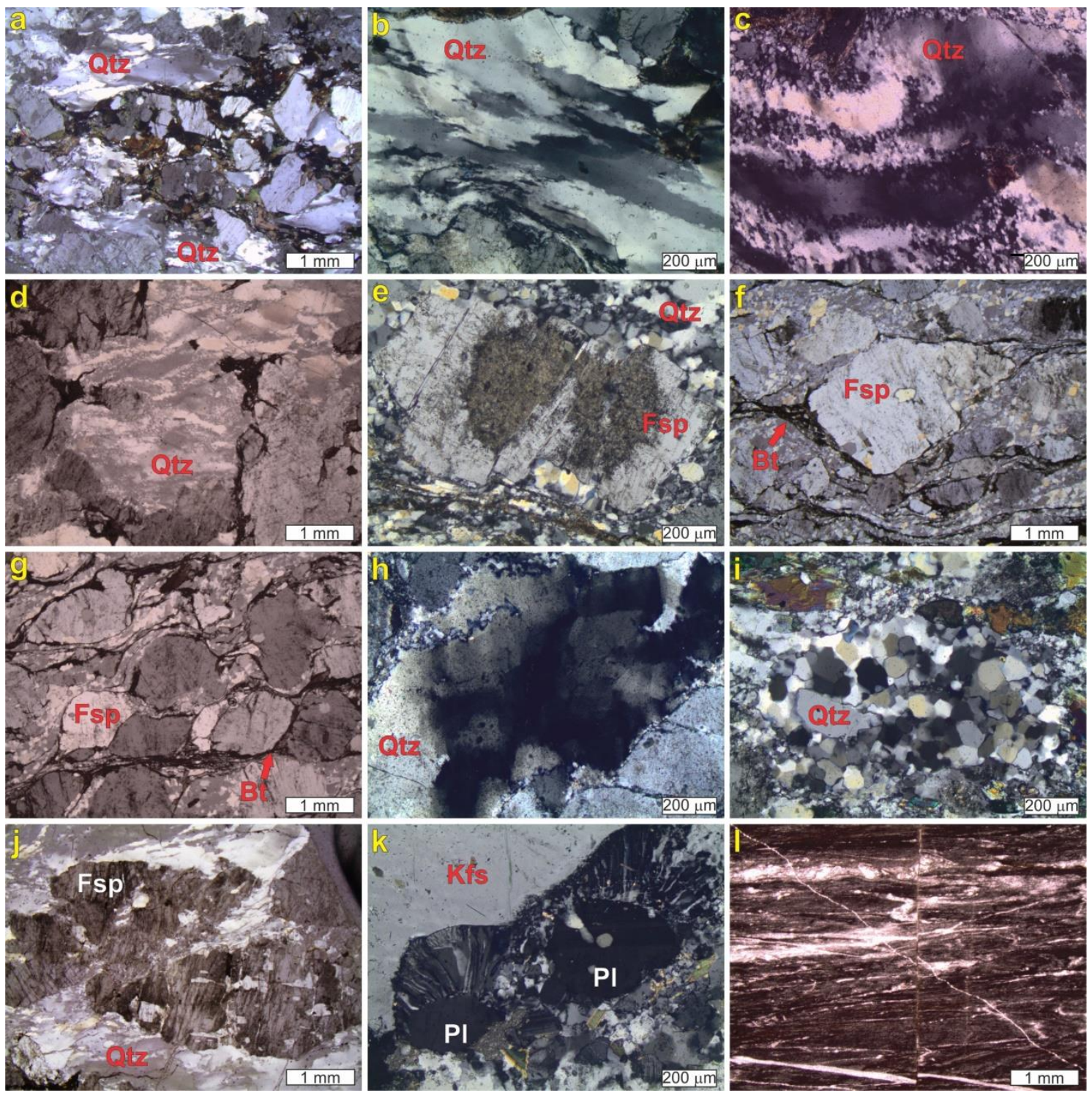

Figura 10. Características microestruturais dos milonitos estudados. (a-g) Milonitos de baixa temperatura apresentando ( $a-b)$ grãos de quartzo estirados e (c-d) recristalizados por bulging, (e-f) grãos de feldspato fraturados (em f, nos cantos superiores) e (f-g) biotita recristalizada bordejando porfiroclastos de feldspato. (h-k) Milonitos de média temperatura apresentando (h) quartzo com recristalização por rotação de subgrão e (i) formando trama poligonal e (j) feldspatos com recristalização incipiente e (k) mirmequita de borda. (l) Ultramilonito apresentando microdobras em $\mathrm{Z}$ indicando cisalhamento destral e microfalhas sinistral ortogonais à foliação milonítica. a-k: com polarizadores cruzados, 1: com polarizadores paralelos. Bt: biotita, Fsp: feldspato, Kf: feldspato potássico, Pl: plagioclásio, Qtz: quartzo.

\section{DISCUSSÃO E CONCLUSÕES}

Utilizando dados gravimétricos e magnéticos em escala regional, Oliveira \& Medeiros (2018) apresentam a divisão da Província Borborema em domínios e subdomínios geofísicos. Nesta divisão, os autores sugerem que o domínio geofísico Zona Transversal (com limites análogos à subprovíncia Central) apresenta um padrão de anomalias compatível com o modelo tectônico de colagem de terrenos. Porém, os subdomínios geofísicos Rio Capibaribe e Garanhuns, localizados nos domínios geofísicos Zona Transversal e Sul, 
respectivamente, a norte e a sul da ZCPE, têm características geofísicas semelhantes. Estes subdomínios geofísicos, no limite dos quais está localizada a área de estudo, são caracterizados por anomalias de baixa densidade e de baixa susceptibilidade. Além disso, a região leste do domínio geofísico Sul e a maior parte do domínio geofísico Zona Transversal são caracterizadas por um mesmo padrão de anomalias com polaridade alternada, sigmoidais e alinhadas paralelamente na direção NE-SW. Para explicar a mesma direção NE-SW nestes domínios geofísicos, Oliveira \& Medeiros (2018) sugeriram que ela poderia ter sido resultante de um estágio de transcorrência tardia, em uma fase de escape lateral da colisão Brasiliana/PanAfricana.

No presente trabalho, a interpretação conjunta dos dados de campo e petrográficos, acrescida aos dados aerogeofísicos e de sensoriamento remoto, nos levou a conclusões diferentes daquela proposta por Oliveira \& Medeiros (2018). A partir dos resultados, pode-se concluir a presença de um mesmo comportamento estrutural dos lineamentos obtidos por aerogeofísica e sensoriamento remoto nos domínios Rio Capibaribe (subprovíncia Central) e PernambucoAlagoas (subprovíncia Sul), além de direções de foliações semelhantes nestes dois domínios, mesmo grau metamórfico das amostras ao longo das faixas miloníticas e metamorfismo regional semelhante, com ocorrência de migmatização a norte e a sul da ZCPE. Estas características identificadas na porção central da ZCPE e a falta de evidências de retrabalhamento indicam que a mesma não separa blocos crustais com características distintas. Portanto, a ZCPE não pode ser considerada como um limite de terrenos.

Os lineamentos de direção NW, marcados no mapa geofísico da derivada tilt (Fig. 6a) e na imagem ASTERGDEM filtrada (Fig. 7a), encontram-se cortando a ZCPE, indicando que representam estruturas posteriores a mesma, prováveis fraturas. Comparando os lineamentos geofísicos (tabela 1) com os lineamentos marcados pelo sensoriamento remoto (tabela 2), em ambos os métodos os lineamentos resultantes de estruturas rúpteis são dominantes e a direção NE-SW contém os lineamentos de maior comprimento. Pelo sensoriamento remoto obteve-se o maior número de lineamentos marcados e, nesta ferramenta, os de direção NESW ganharam mais destaque.

\section{Agradecimentos}

RHMF agradece a bolsa de estudos concedida pela agência CAPES. Os autores agradecem ao Serviço Geológico Brasileiro (CPRM) por disponibilizar os dados geofísicos utilizados nesse trabalho e ao revisor Tiago S. Miranda por comentários e sugestões. Este trabalho foi financiado pelo Conselho Nacional de Desenvolvimento Científico e Tecnológico (Processo 449447/2014-6).

\section{REFERÊNCIAS}

Brito Neves, B.B., 1983. O mapa geológico do Nordeste oriental do Brasil, escala 1/1.000.000. Tese de doutorado, Concurso de Livre Docência - USP. 177 p.

Brito Neves, B.B., Sial, A.N., Rand, H.M., Manso, V.V., 1982. The Pernambuco-Alagoas massif, northeastern Brazil. Revista Brasileira de Geociências, 12 (13): 240-250.

Caby, R., Sial, A.N., Arthaud, M.H., Vauchez, A., 1991. Crustal evolution and the Brasiliano orogeny in Northeast Brazil. In: Dallmeyer, R.D., Lécorché , J.P. (Eds.), The West African Orogens and Circum-Atlantic Correlatives. Springer-Verlag, Berlin, p. 373397. 
Da Silva Filho, A.F., Guimarães, I.P., Van Schmus, W.R., 2002. Crustal evolution of the PernambucoAlagoas Complex, Borborema Province, NE Brazil: Nd Isotopic Data from Neoproterozoic Granitoids. Gondwana Research, 5 (2): 409-422.

Davison, I., McCarthy, M., Powell, D., Torres, H.H.F., Santos, C.A., 1995. Laminar flow in shear zones: the Pernambuco Shear Zone, NEBrazil. Journal of Structural Geology, 17 (2): 149-161.

Earth Explorer, USGS. Disponível em: <www.earthexplorer.usgs.gov>. Acesso em: 06 de junho de 2017.

Gomes, H.A., 2007. Geoquímica e Contexto Tectônico de Leucogranitos Peraluminosos do Batólito Bonito-Gameleira, Domínio Pernambuco-Alagoas, Província Borborema, NE do Brasil. Tese de doutorado, PósGraduação em Geociências UFPE. $173 \mathrm{p}$.

Hidalgo-Gato, M.C., 2015. Realce e Detecção de Feições Magnéticas Através do Sinal Monogênico no Espaço-Escala de Poisson: Fundamentos e Princípios. Dissertação de mestrado, PósGraduação em Geofísica ON/MCTI. $71 \mathrm{p}$.

LASA Engenharia e Prospecções S/A e PROSPECTORS

Aerolevantamentos e Sistemas Ltda, 2008. Projeto Aerogeofísico Borda Leste do Planalto da Borborema - Relatório Final do Levantamento e Processamento dos Dados Magnetométricos e Gamaespectrométricos, Ministério de Minas e Energia, Secretaria de Geologia, Mineração e Transformação Mineral, CPRM Serviço Geológico do Brasil, Relatório Final, 27 vol, Texto e Anexos (Mapas), Rio de Janeiro.
Medeiros, V.C., Torres, H.H.F., Gomes, H.A., 2000. Geologia da Folha Sumé - SB.24-Z-D-V, escala 1:100.000. CPRM - Serviço Geológico do Brasil.

Meneses, P.R., Almeida, T.de., 2012. Introdução ao Processamento de Imagens de Sensoriamento Remoto. UnB/CNPq, Brasilia, p. 176-179.

Miller, H.G., Singh, V., 1994. Potential field tilt - a new concept for location of potential field sources. Journal of Applied Geophysics, 32: 213-217.

Neves, S.P., 2003. Proterozoic history of the Borborema province (NE Brazil): Correlations with neighboring cratons and PanAfrican belts and implications for the evolution of western Gondwana. Tectonics, 22 (4).

Neves, S.P., 2015. Constrains from zircon geochronology on the tectonic evolution of the Borborema Province: Widespread intracontinental Neoproterozoic reworking of a Paleoproterozoic accretionary orogen. Journal of South American Earth Sciences, 58: $150-164$.

Neves, S.P., Alcantara, V.C., 2010. Geochemistry of orthogneisses and metasedimentary rocks across a proposed terrane boundary in the Central Domain of Borborema Province, NE Brazil: geodynamic implications. Journal of South American Earth Sciences, 29: 498511.

Neves, S.P., Mariano, G., 1999. Assessing the tectonic significance of a large-scale transcurrent shear zone system: the Pernambuco lineament, northeastern Brazil. Journal of Structural Geology, 21(10): 1369-1383.

Neves, S.P., Vauchez, A., 1995. Magma emplacement and shear zone nucleation and development in 
northeast Brazil (Fazenda Nova and Pernambuco shear zones; state of Pernambuco). Journal of South American Earth Sciences, 8 (3-4): 289-298.

Neves, S.P., Vauchez, A., Archanjo, C.J., 1996. Shear zone-controlled magma emplacement or magmaassisted nucleation of shear zones? Insights from northeast Brazil. Tectonophysics, 262: 349-365.

Neves, S.P., Vauchez, A., Feraud, G., 2000. Tectono-termal evolution, magma emplacement, and shear zone development in the Caruaru area (Borborema Province, NE Brazil). Precambrian Research, 99: 1-32.

Neves, S.P., Melo, S.C., Moura, C.A.V., Mariano, G., Silva, J.M.R., 2004. Zircon $\mathrm{Pb}-\mathrm{Pb}$ Geochronology of the Caruaru Area, Northeastern Brazil: Temporal Constraints on the Proterozoic Evolution of Borborema Province. International Geology Review, 46: 52-63.

Neves, S.P., Mariano, G., Correira, P.B., Silva J.M.R., 2006a. 70 m.y. of synorogenic plutonism in eastern Borborema Province (NE Brazil): temporal and kinematic constraints on the Brasiliano Orogeny. Geodinamica Acta, 19 (3-4): 213237.

Neves, S.P., Brugueir, O., Vauchez, A., Bosch, D., Silva, J.M.R., Mariano, G., 2006b. Timing of crust formation, deposition of supracrustal sequences, and Transamazonian and Brasiliano metamorphism in the East Pernambuco belt (Borborema Province, NE Brazil): Implications for western Gondwana assembly. Precambrian Research, 149: 197216.

Neves, S.P., Bruguier, O., Silva, J.M.R., Delphine Bosch, D., Alcantara, V.C., Lima, C.M., 2009. The age distributions of detrital zircons in metasedimentary sequences in eastern Borborema Province (NE Brazil): evidence for intracontinental sedimentation and orogenesis? Precambrian Research, 175: 187-205.

Neves, S.P., Mariano, G., Silva, H.M.R., 2012a. Geologia da Folha Caruaru - SC.25-V-A-I, escala 1:100.000. CPRM - Serviço Geológico do Brasil.

Neves, S.P., Monié, P., Bruguier, O. Silva, J.M.R., 2012b. Geochronological, thermochronological and thermobarometric constraints on deformation, magmatism and thermal regimes in eastern Borborema Province (NE Brazil). Journal of South American Earth Sciences, 38: 129-146.

Neves, S.P., Bruguier, O., Silva, J.M.R., Mariano, G., 2015a. From extension to shortening: dating the onset of the Brasiliano Orogeny in eastern Borborema Province (NE Brazil). Journal of South American Earth Sciences, 58: 238-256.

Neves, S.P., Lages, G.A., Brasilino, R.G., Miranda, A.W., 2015b. Paleoproterozoic accretionary and collisional processes and the buildup of the Borborema Province (NE Brazil): Geochronological and geochemical evidence from the Central Domain. Journal of South American Earth Sciences, 58: 165187.

Neves, S.P., Mariano, G., Silva, J.M.R., 2017. Geologia e recursos minerais da Folha Surubim SC.25-Y-C-IV, escala 1:100.000. CPRM - Serviço Geológico do Brasil.

Oliveira, R.G., Medeiros, W.E., 2018. Deep crustal framework of the Borborema Province, NE Brazil, derived from gravity and magnetic data. Precambrian Research, 315: 45-65. 
Ribeiro, V.B., Louro, V.H.A., Mantovani, M.S.M., 2015. Apostila Prática - volume 2. Processamento e Interpretação de Dados Geofísicos Aeromagnetometria. LIGA Laboratório de Interpretação em Geofísica Aplicada, UFPE. GEOLIT, IAG, USP, 47 p.

Santos, E.J., Ferreira, S.A., Silva Jr., J.F., 2002. Geologia e Recursos Minerais do Estado da Paraíba. Ministério de Minas e Energia Secretaria de Minas e Metalurgia. CPRM - Serviço Geológico do Brasil.

Teixeira, C.M.L., 2015. Evolução Crustal dos Domínios Central e Pernambuco-Alagoas da Província Borborema na Folha Vitória de Santo Antão (Pernambuco, Nordeste do Brasil). Tese de doutorado, Pós-Graduação em Geociências - UFPE. 182 p.

Van Schmus, W.R., Kozuch, M., Brito Neves, B.B., 2011. Precambrian history of the Zona Transversal of the Borborema Province, NE Brazil: Insights from Sm-Nd and $\mathrm{U}-\mathrm{Pb}$ geochronology. Journal of South American Earth Sciences, 31: 227-252.

Vauchez, A., Egydio-Silva, M., 1992. Termination of a continental-scale strike-slip fault in partially melted crust: the West Pernambuco shear zone, northeast Brazil. Geology, 20: 1007-1010.

Vauchez, A., Neves, S., Caby, R., Corsini, M., Egydio-Silva, M., Arthaud, M., Amaro, V., 1995. The Borborema shear zone system, NE Brazil. Journal of South American Earth Sciences, 8 (3-4): 247-266. 